\title{
ANALISIS PROKSIMAT, KANDUNGAN COLIFORM, DAN UJI HEDONIS MINUMAN FUNGSIONAL SIAP SAJI BERBAHAN DASAR CAMPURAN JAHE, SEREH, SECANG, PALA, CENGKEH, DAN KAPULAGA
}

\author{
Asriadi Masnar, Dimas Bayu Pinandoyo \\ Culinary Art, Manajemen Perhotelan, Politeknik Negeri Media Kreatif, Jakarta Selatan \\ Email Korespondensi : asriadi.masnar@polimedia.ac.id
}

\begin{abstract}
ABSTRAK
Tren peningkatan permintaan akan minuman siap saji menawarkan peluang besar terhadap ceruk pasar produk minuman yang berkhasiat untuk kesehatan. Namun, sebagian besar dari produsen tidak menyajikan data krusial kepada publik dan rasa yang ditawarkan terlalu kuat menjadi tantangan tersendiri untuk memasarkan produk di antara gempuran produk minuman yang memiliki banyak varian rasa. Penelitian ini bertujuan ini untuk memaparkan aspek kandungan proximat, uji keawetan (kandungan coliform) dan uji preferensi terhadap minuman fungsional siap saji berbahan dasar utama jahe, sereh, secang, pala, cengkeh, dan kapulaga yang lebih dikenal secara komersil dengan sebutan bir pletok dengan rentang waktu penelitian 4 bulan (Agustus-November 2019). Kandungan antioksidan, energi, lemak, kadar air, abu protein, dan karbohidrat diperoleh dari hasil uji di Laboratorium Pusat Studi Biofarmaka, Institut Pertanian Bogor dengan uji DPPH (1,1-Diphenyl-2-Picryl Hidrazil) dengan teknik analisis Spektrofotometri, Gravimetri dan Kjeldahl. Hasil uji Coliform diperoleh dari Laboratorium Mikrobilogi Fakultas Kedokteran Gigi, Universitas Indonesia dengan Metode Most Probably Number (MPN). Uji hedonis diperoleh dari hasil uji menggunakan skala likert. Hasil yang diperoleh menunjukkan bahwa diperlukan 1480.34 ppm (part per million) untuk dapat menangkap radikal bebas. Energi yang diperoleh sebesar 43,63 kkal/100gr, kadar air 88,9\%, abu 0.28\%, lemak $0,07 \%$, Protein $0 \%$, Karbohidrat $10,75 \%$. Hasil uji coliform menunjukkan pada hari ke tiga 10 koloni muncul pada produk minuman ini yang diformulasi tanpa pengawet Natrium Benzoat. Dari 16 responden yang mengikuti uji hedonis diperoleh rata-rata nilai sebesar 4,04 dalam hal ini semua responden menyatakan sensasi rasa dan aroma produk yang kuat.
\end{abstract}

Kata kunci: Bir pletok; minuman kesehatan; uji organoleptik; uji preferensi

\begin{abstract}
The increasing demand for ready-to-serve beverages offers a great opportunity towards market healthy beverage products. However, most manufacturers do not provide important data to the public and its strong taste is unique challenge in marketing products amid the flood of trendy beverage products. This study aims to present aspects of proximal content, preservation test (coliform content) and preference tests on fast food functional drinks based on commercial ginger, lemongrass, lentils, cloves, cloves, and cardamom within 4 month study (August-November 2019). The content of antioxidants, energy, fat, water, protein ash, and carbohydrates were obtained from tests at the Biofarmaka Study Laboratory, Bogor Agricultural University by established a novel DPPH test (1,1-Diphenyl-2-Picryl Hydrogen) with Spectrophotometry, Gravimetric, Kjeldahl analysis techniques. Coliform test results were obtained from the Microbiology Laboratory of the Faculty of Dentistry, University of Indonesia with the Most Probably Number (MPN) Method. The hedonic test is obtained from a test using a Likert scale. The results showed that it takes 1480.34 ppm (parts per million) to capture free radicals. Energy $43.63 \mathrm{kcal} / 100 \mathrm{gr}$, water content $88.9 \%$, ash $0.28 \%$, fat $0.07 \%$, protein $0 \%$, carbohydrate $10.75 \%$. Coliform test results showed that on the third dy 10 colonies appearing on this beverage product which were formulated without Sodium Benzoate. All 16 respondents who took the hedonistic test, average rating of 4.04 expressed strong taste and aroma of the product.
\end{abstract}

Keywords: Bir pletok, healthy drink, organoleptic test; preference test 
Masnar, 2020

PENDAHULUAN

$$
\text { Beberapa peneliti melaporkan }
$$

pengeluaran biaya kesehatan dapat diturunkan hingga 20\% dengan mengonsumsi makanan dan minuman fungsional (Otles, 2012). Produkproduk populer minuman lokal asli sudah ada sejak awal sejarah dan telah menjadi bagian tak terpisahkan dari diet sehari-hari di rumah tangga atau di industri rumahan. Proses produksinya menggunakan teknik dan peralatan yang relatif sederhana melalui proses penumbukan, pemerasan, dan pengeringan. Tidak hanya mengawetkan produk makanan tetapi juga meningkatkan status gizi, berfungsi sebagai bumbu atau makanan pembuka, dan untuk pengembangan ekonomi sektor nonformal (Surono, 2016; Laplante, 2016). Bahan dasar produk herbal ini mengandung berbagai macam fitonutrien yang terbukti bermanfaat terhadap kesehatan manusia (Thiagarajah, 2019).

Beberapa produk minuman tradisional yang ada di Indonesia seperti Sarabba, Bandrek, Minuman Secang, dan Bir Pletok mengandung antioksidan. Komponen antikoksidan dari produk tersebut adalah brazilin, zingiberen, gingerol, shogaol (jahe), eugenol (cengkeh), geraniol, citronellal, citronellol, lemonene (sereh), sineol, sinamaldehida (kayu manis), cineol, dan pinen (kapulaga), myristicin dan safrol (pala). Komponen aktif dari tersebut berkhasiat sebagai antibakteri, antivirus, antiinflamasi, antialergi, antitrombosis, dan bepersan dalam vasodilatasi (Chandrasekara, 2018; Gao, 201; Bender, 2014). Studi mengenai konsumen yang berfokus pada preferensi dan penerimaan konsumen terhadap minuman tradisonal yang antioksidan masih terbatas. Hal yang yang mempengaruhi preferensi dan penerimaan seseorang pada umumnya dipengaruhi oleh faktor internal (pengetahuan, gender, usia, kondisi psikologis, kemampuan sensoris dan pengalaman) dan faktor eksternal (demografi, status social) (Thomson, 1994; Pasqualone, 2018). Menurut Kementerian Perindustrian mencatat industri makanan dan minuman tumbuh sebesar 7,91\% sepanjang tahun lalu. Dari 2014 hingga 2018, sektor ini mencatatkan pertumbuhan yang relatif lebih tinggi dibandingkan sektor lainnya dan menjadi salah satu sektor unggulan pengembangan industri pengolahan ke depan (Rini, 2019).

Penelitian ini memiliki tiga tujuan penelitian yakni pertama, untuk mengetahui kandungan nutrisi pada minuman fungsional siap saji berbahan dasar campuran jahe, sereh, secang, pala, cengkeh, dan kapulaga yang beredar di pasaran dalam bentuk sediaan cair siap minum. Kedua mengetahui kandungan bakteri coliform dalam produk dan ketiga memeroleh informasi mengenai evaluasi sensoris terhadap jenis produk ini yang kurang mengalami modifikasi rasa sehingga produsen dapat melakukan evaluasi rasa terhadap produk yang sudah ada.

\section{METODE}

Rentang waktu penelitian berlansung selama 4 bulan (Agustus-November 2019). Sampel diperoleh dari UKM (Usaha Kecil dan 
Masnar , 2020

Menengah) Bir Pletok Cakung dilakukan di Cakung, RT.4/RW.9, Cakung Barat, Kecamatan Cakung, Kota Jakarta Timur, DKI Jakarta. Analisis Proximat dilakukan di Laboratorium Pusat Studi Biofarmaka, Institut Pertanian Bogor.

Uji Coliform dilaksanakan dI Laboratorium Mikrobilogi Fakultas Kedokteran Gigi, Universitas Indonesia. Analisis antioksidan menggunakan metode analisis antioksidan IC50 DPPH untuk mengetahui kemampuan untuk menangkap radikal bebas suatu bahan atau sampel. Pada analisis ini, kemampuan antioksidan bir pletok dibandingkan dengan menggunakkan standar dari vitamin $\mathrm{C}$ dalam bentuk serbuk. Sebelum pemeriksaan antioksidan sampel bir pletok dimasukkan dalam rotar terlebih dahulu untuk menghilangkan padatan dan gula untuk mengurangi risiko galat pada spektrofotometri.

Pengujian ini dilakukan dengan dua tahapan yaitu Uji Penduga (Presumtive Test) dan Uji Konfirmasi (Confirmative Test) (Bambang,2014). Pengenceran terdiri dari $10^{-1}$, $10^{-2}$ dan $10^{-3}$ diambil sebanyak $1 \mathrm{ml}$ dan masingmasing dimasukan ke dalam 3 tabung yang berisi $9 \mathrm{ml}$ media Lactose Broth (LB). Kemudian, sampel diinkubasi selama 24-48 jam dengan suhu $37^{\circ} \mathrm{C}$. Tabung yang terdapat gas diamati dan dicatat dilanjutkan dengan uji uji konfirmasi. 1 ose sampel dipindahkan ke dalam tabung yang berisi $9 \mathrm{ml}$ media Brilliant Green Lactose Bile
Broth (BGLBB) dan dilengkapi dengan tabung durham terbalik. Kemudian, semua tabung diinkubasi pada suhu $37^{\circ} \mathrm{C}$ dalam kurun waktu 24-48 jam. Hasil positif diperoleh jika terbentuk gas atau gelembung dalam tabung durham. Gas pada uji penegas dan disesuaikan dengan tabel Most Probably Number (MPN) sesuai standar SNI 01-2332.1-2006 (Badan Standardisasi Indonesia, 2009). Angket digunakan sebagai instrumen survei untuk menentukan indikator mana yang akan digunakan dalam percobaan lebih lanjut. Kuesioner terdiri dari deskripsi produk dan informasi umum responden dan tabel terdiri jenis pertanyaan tertutup mengenai indikator rasa, aroma, sensasi di mulut, sensasi setelah pencicipan (after taste) dan warna. Validitas dan uji reliabilitas dilakukan untuk memvalidasi kuesioner sebelum digunakan kepada 16 responden. Responden diinstrusikan untuk mencicipi sampel dengan 5 skala hedonis dari $1=$ sangat tidak suka hingga ke 5 = sangat suka. Sampel disajikan pada suhu $28^{\circ} \mathrm{C}$.

\section{HASIL}

\section{Hasil Analisis Kandungan Zat Gizi Makro dan Antioksidan Bir Pletok}

Analisis yang dilakukan adalah analisis antioksidan IC50 - DPPH, Energi Total, Energi Lemak, Kadar Air, Kadar Abu, Lemak Total, Protein dan Karbohidrat Total. Adapun hasil analisis dapat dilihat pada tabel 1 berikut : 
Tabel 1. Hasil Analisis Kandungan Zat Gizi Makro dan Antioksidan sampel

Kondisi Sediaan $\quad$ Parameter Pengukuran Hasil Teknis Analisis

\begin{tabular}{cccc}
\hline Padatan & Antioksidan IC50-DPPH & $1480,34(\mathrm{ppm})$ & Spektrofometri \\
Cairan & Energi Total & $43,63(\mathrm{kkal} / 100 \mathrm{~g})$ & Kalkulasi \\
& Energi dari Lemak & $0.63(\mathrm{kkal} / 100 \mathrm{~g})$ & Gravimetri \\
Kadar Air & $88,90 \% \%$ & Gravimetri \\
Kadar Abu & $0,28 \% \%$ & Gravimetri \\
Lemak Total & $0,07 \%$ & Gravimetri \\
Protein & 0 & $\%$ & Kjeldahl \\
Karbohidrat Total & 10,75 & $\%$ & Gravimetri \\
\hline
\end{tabular}

Sebelum pemeriksaan antioksidan sampel bir pletok dirotar terlebih dahulu untuk memeroleh sampel yang seragam dan memisahkan gula yang dapat mengganggu pembacaan oleh spektrofotometri. Pemeriksaan antioksidan menggunakan alat spektrofotometri dan diperoleh hasil bahwa pada sampel diperlukan 1480.34 ppm untuk dapat menangkap radikal bebas. Dari ini dapat disimpulkan bahwa sampel ini merupakan minuman dengan aktivitas antioksidan yang rendah. Hal ini merujuk penelitian Badarinath (2010) bahwa suatu senyawa dikatakan sebagai antioksidan sangat kuat jika nilai IC50 kurang dari 50 ppm, kuat (50-100 ppm), sedang (100150 ppm), dan lemah (151-200 ppm). Jadi, semakin kecil nilai IC50 semakin tinggi aktivitas antioksidan. Dapat disimpulkan bahwa, sampel minuman ini tergolong minuman dengan antioksidan lemah.

\section{Nilai Most Probable Number (MPN)}

Hasil penelitian menunjukan bahwa nilai Most Probable Number (MPN) sampel tanpa pengawet $\mathrm{Na}$ Benzoat hari pertama dan kedua tidak terdapat bakteri namun pada hari ketiga tampak 10 koloni dan meningkat secara eksponensial pada hari berikutnya menjadi 135 . Di hari kelima dan hari ke enam masing-masing menjadi 375 dan 781. Di hari ketujuh tampak 1500 koloni, sedangkan pada hari kedelapan hingga hari ketiga puluh koloni sangat banyak dan sulit untuk dihitung. 
Gambar 1. Kandungan Coliform Bir Pletok (Colonies/ml)

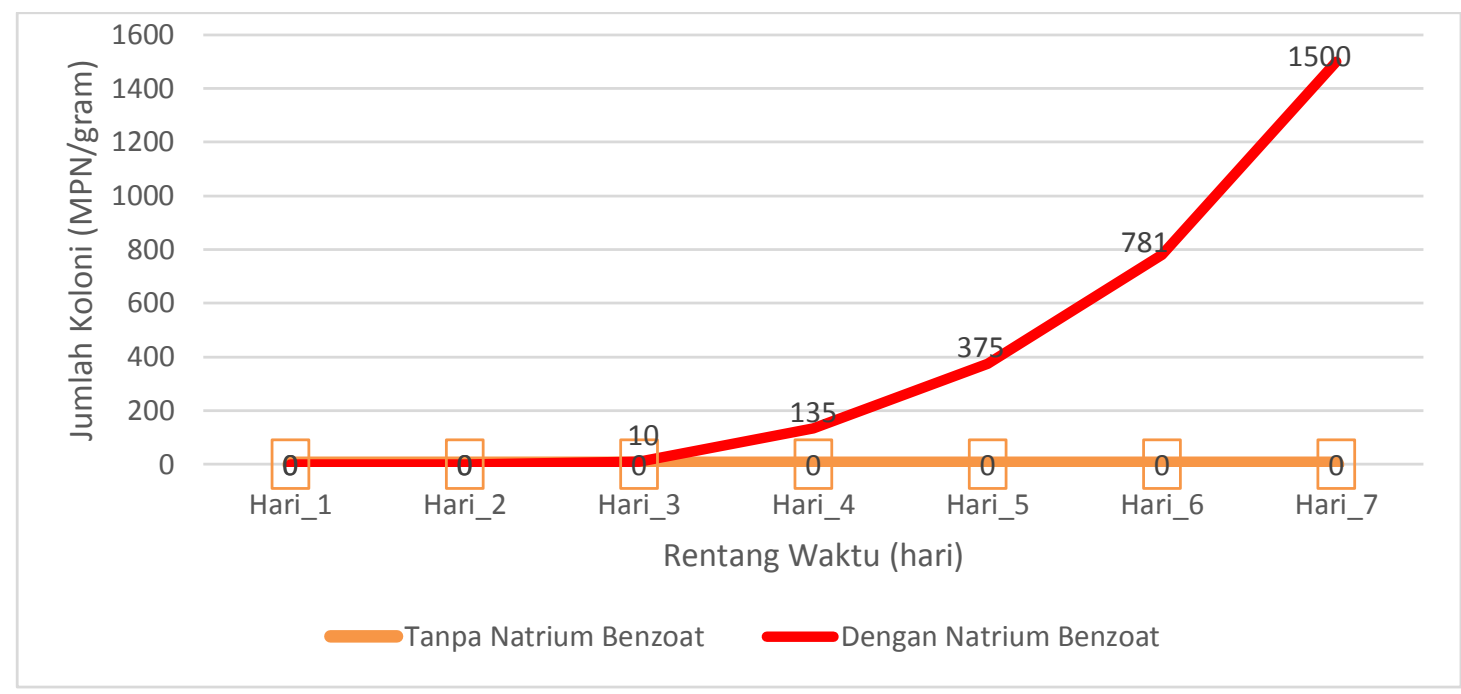

Penggunaan 0,5 g/l natrium benzoat dalam produk makanan masih dalam tahap aman untuk dikonsumsi namun jika melebihi konsumsi yang melebihi ambang batas yang ditetapkan dapat berdampak pada kesehatan.

\section{Uji Penerimaan dan Preferensi}

Dalam uji ini jumlah responden pria sebanyak 9 orang dan wanita sebanyak 7 orang. Hasil tes penerimaan dan preferensi konsumen ini menggunakan skala likert dengan kategori (1) tidak suka, (2) Agak Tidak Suka, (3) netral, (4) Sedikit Suka, (5) Suka. Hasil analisis menunjukan bahwa dari segi rasa dan aroma semua responden menyatakan sedikit suka dengan nilai rata-rata yang sama yakni 4,25 . Sensasi di mulut dan warna memiliki rata-rata sebesar 3,93 dan 3,81 berturut-turut; hal ini menunjukkan bahwa rata- rata responden cenderung netral terhadap kedua aspek tersebut. Sensasi pedas dihasilkan oleh senyawa gingerol. Selain itu senyawa dalam jumlah kecil memberikan sensai pedas shogaol (fenilalanone) (Ravindran, 2016). Warna yang dihasilkan oleh produk ini adalah dominan warna merah yang berasaldari secang. Kandungan kimia kayu secang adalah salah satunya adalah Brazilin $\left(\mathrm{C}_{6} \mathrm{H}_{14} \mathrm{O}_{5}\right)$ yang berfungsi sebagai antiviral, antitumor, antifungal, dan antibacterial (Badami,2004). Brazilin yang mengalami reaksi pemanasan akan terurai menjadi senyawa brazilein dengan warna khas merah gelap. Dari aspek after taste atau sensasi rasa setelah minum dan kekuatan rasa nilai yang diperoleh adalah sedikit suka dengan skor masing-masing 4. 
Tabel 2. Tabulasi Data Uji Hedonik

\begin{tabular}{cccccccc}
\hline No & Rasa & Aroma & $\begin{array}{c}\text { Sensasi Di } \\
\text { mulut }\end{array}$ & $\begin{array}{c}\text { After } \\
\text { Taste }\end{array}$ & Warna & $\begin{array}{c}\text { Kekuatan } \\
\text { Rasa }\end{array}$ & Gender \\
\hline 1 & 3 & 4 & 2 & 3 & 3 & 3 & $\mathrm{P}$ \\
2 & 5 & 5 & 4 & 5 & 5 & 4 & $\mathrm{P}$ \\
3 & 5 & 5 & 4 & 5 & 5 & 4 & $\mathrm{P}$ \\
4 & 4 & 5 & 5 & 5 & 4 & 4 & $\mathrm{P}$ \\
5 & 5 & 5 & 3 & 5 & 4 & 3 & $\mathrm{P}$ \\
6 & 2 & 4 & 2 & 2 & 5 & 4 & $\mathrm{~L}$ \\
7 & 5 & 4 & 5 & 4 & 2 & 3 & $\mathrm{~L}$ \\
8 & 4 & 4 & 3 & 4 & 5 & 4 & $\mathrm{~L}$ \\
9 & 5 & 4 & 5 & 3 & 3 & 4 & $\mathrm{P}$ \\
10 & 4 & 5 & 4 & 5 & 5 & 5 & $\mathrm{~L}$ \\
11 & 5 & 4 & 5 & 4 & 4 & 4 & $\mathrm{~L}$ \\
12 & 4 & 4 & 5 & 3 & 3 & 5 & $\mathrm{P}$ \\
13 & 5 & 3 & 2 & 5 & 5 & 5 & $\mathrm{~L}$ \\
14 & 4 & 3 & 4 & 3 & 3 & 3 & $\mathrm{~L}$ \\
15 & 4 & 4 & 5 & 3 & 2 & 5 & P: 7 L:9 \\
16 & 4 & 5 & 5 & 5 & 3 & 4 & Rerata $\ddot{x}=$ \\
$\sum$ & 68 & 68 & 63 & 64 & 61 & 64 & 4,04 \\
$\ddot{\mathbf{x}}$ & 4,25 & 4,25 & 3,93 & 4 & 3,81 & 4 &
\end{tabular}

\section{PEMBAHASAN}

Pembuatan resep minuman ini mengacu pada resep secara umum yakni dengan menggunakan bahan yaitu air, jahe, sereh, cengkeh, kapulaga, secang, kayu manis, pala, gula pasir dan garam. Selanjutnya rempahrempah tersebut yang direbus dalam satu wadah. Air rebusan ini yang menjadi minuman bir pletok. Komponen aktif (antioksidan) yang terkandung di dalam minuman ini adalah brazilin dan brazilein (secang) (Nirmal, 2015), zingiberen, gingerol, shogaol (jahe) (Chrubasik, 2005), eugenol (cengkeh)(Ahmad and Viljoen, 2015), geraniol, citronellal, citronellol, lemonene (sereh) (Hernandez, 2000), sineol, sinamaldehida (kayu manis) (Anto, 2018), cineol, dan pinen (kapulaga) (Parthasarathy, 2012), myristicin dan safrol (pala) (Periasamy, 2016).

Komponen aktif dari rempah-rempah tersebut mempunyai khasiat yang beragam, terutama dapat mencegah timbulnya penyakit degeneratif, seperti kanker, jantung koroner, stroke, diabetes mellitus, hipertensi, artritis, parkison, alzheimer, katarak, serta berbagai kasus penuaan dini. Sementara itu penambahan gula pada bir pletok ini tidak mempengaruhi 
Masnar , 2020

keberadaan antioksidan karena sukrosa bukan merupakan gula pereduksi karena sukrosa cenderung mengalami hidrolisis (Chandrasekara, 2018; Winarti, 2005; Zulfahmi, 2017).

Prinsip dasar dari metode DPPH didasarkan pada reduksi dari larutan methanol radikal bebas DPPH yang berubah waarna yang diakibatkan oleh radikal bebas. Ketika larutan DPPH yang berwarna ungu bertemu dengan bahan pendonor elektron maka DPPH akan tereduksi, menyebabkan warna ungu akan memudar dan digantikan warna kuning yang berasal dari golongan pikril yakni senyawa difenil pikrilhidrazin (non radikal) (Molyneux, 2004; Tristantini, 2016).

Perhitungan kadar antioksidan metode $\mathrm{IC}_{50}$ diperoleh dengan:

$$
\% \text { antioksidan }=\frac{A c-A}{\mathrm{Ac}} \times 100 \%
$$

Keterangan :

Ac $=$ Nilai absorbansi kontrol

A $=$ Nilai absorbansi sampel

Kadar abu adalah parameter nilai kandungan bahan anorganik (mineral) yang terkandung dalam suatu bahan atau produk. Nilai kadar abu berbanding lurus dengan kuantitas kandungan bahan anorganik di dalam produk tersebut. Dari aspek analisis proksimat, Berdasarkan standar yang ditetapkan oleh SNI (1996), nilai kadar abu untuk serbuk minuman tradisional maksimal 1.5\%, sampel telah memenuhi standar tersebut. Lebih lanjut, energi total yang dihasilkan 43,63 kkal/100gr dan energi dari lemak sebesar $0.63 \mathrm{kkal} / 100 \mathrm{gr}$ nilai ini cukup rendah dibandingkan standar mutu Syarat Mutu
Minuman Serbuk Instan Tradisional bahwa jumlah gula maksimal $85 \%$.

Bakteri Coliform merupakan jenis bakteri yang digunakan menunjukkan kemungkinan adanya mikroorganisme yang berbahaya bagi kesehatan. Infeksi Coliform yang masuk ke dalam tubuh dalam jangka waktu singkat adalah dehidrasi, diare, kram perut, mual, dan rasa letih. Dalam jangka lama akan menyebabkan tinja bercampur dengan darah dan demam tinggi. Kualitas mikrobiologis adalah atribut kunci untuk menunjukkan integritas produk makanan dan kebersihan pengolahan makanan. Coliforms dan E. coli Detection telah diadopsi oleh industri makanan kelas dunia dalam menentukan kualitas mikrobiologis dari produk makanan (Bredie, 1992). Deteksi E. coli menunjukkan kontaminasi yang berasal baik langsung atau tidak langsung dari manusia dan hewan berdarah panas. Jumlah E. coli dan Total coliform (TC) dalam sampel makanan secara langsung menyiratkan praktik buruk dalam penanganan dan produksi makanan dan aktivitas penyajian (Sangadkit, 2012).

Penelitian yang dilakukan oleh Yan Shu dkk (2016) terhadap hewan percobaan di laboratorium mengenai dampak konsumsi asam benzoat. Suplementasi asam benzoat $0,5 \%$ dalam diet memiliki efek menguntungkan pada subjek percobaan, tetapi suplementasi asam benzoat berlebihan $(2,5 \%$ dan $5,0 \%)$ dalam diet dapat menyebabkan keterlambatan pertumbuhan, kelainan hematologis dan cedera beberapa organ (hati dan limpa). 
Masnar, 2020

Sampel kedua yakni dengan Natrium Benzoat 0,5 g/l di hari pertama hingga hari ketiga puluh tidak ditemukan satupun koloni. Hal ini menunjukkan dengan dosis tersebut, pengawet natrium benzoat efektif mengawetkan produk hingga sebulan tanpa ada perubahan aspek organoleptik dan memenuhi syarat kemanan pangan dari Permenkes RI No.492 tahun 2010 sebesar 0/100ml. Kuantitas Natrium Benzoat dalam minuman ini masih dalam jumlah yang aman namun jika dikonsumsi berlebih (sekitar $450 \mathrm{mg} / \mathrm{kg}$ berat badan) (WHO, 2005).

Pemenuhan keinginan konsumen merupakan hal yang wajib terhadap produk komersil terutama tuntutan mengenai rasa dan aroma yang terkait dengan pengideraan sifat produk yang terkait dengan kualitas produk. Kualitas produk yang relevan sangat berkaitan dengan kepuasan pelanggan yang berpengaruh langsung dengan penjualan produk (Pecore, 2002). Metode pengujian sensorik afektif menggunakan hedonics (tingkat kesukaan) untuk memeroleh respon sensoris emotif dari penilai. Mereka dinilai berdasarkan preferensi mereka atau pada 'kesukaan' mereka akan hal-hal seperti penampilan, rasa, atau tekstur dan pada akhirnya kesan keseluruhan mereka terhadap suatu produk. Tes penerimaan dan preferensi dapat digunakan untuk menentukan secara kualitatif dan kuantitatif apakah konsumen menyukai produk yang dimodifikasi serta memperhitungkan perbedaan karena usia dan jenis kelamin serta pengaruh budaya (Yusop, 2009; Michon, 2010) dan digunakan untuk menentukan apakah perlu formulasi modifikasi pada produk dan hemat biaya.

Senyawa kimia dalam sereh adalah sitronellal dan geraniol. Senyawa tersebut menentukan intensitas aroma sereh yang memberi efek tenang (Goes,2015). Kapulaga mengandung minyak atsiri yaitu $\alpha$-pinene, $\beta$-pinene, $p$ cimene, cineol and terpineol yang membentuk aroma khas kapulaga (Fachriyah, 2012). Selanjutnya dari riset yang telah ada menunjukkan bahwa konsumsi ekstrak kapulaga berpotensi menjadi antiatherogenik dan menurunkan kadar glukosa darah (Winarsi, 2013). Secara keseluruhan produk penilaian produk ini menunjukkan bahwa setiap aspek tidak melebihi tingkatan "sedikit suka" sehingga akan sulit bersaing dengan minuman populer yang berkembang saat ini dimana target marketnya adalah anak muda. Dibutuhkan modifikasi rasa dan kemasan minuman berbahan rempah dan sejenis ini agar dapat bersaing dengan produk minuman yang marak saat ini.

\section{KESIMPULAN DAN SARAN}

Sampel yang diteliti menunjukkan bahwa diperlukan 1480.34 ppm (part per million) untuk dapat menangkap radikal bebas dan tergolong antioksidan golongan rendah. Dari hasil analisis proksimat menunjukkan Energi yang diperoleh sebesar 43,63 kkal/100gr, kadar air 88,9\%, abu $0.28 \%$, lemak 0,07\%, Protein 0\%, Karbohidrat 10,75\%. Dengan penambahan Natrium Benzoat produk dapat awet hingga 30 hari, sedangkan tanpa pengawet di hari ke tiga koloni sudah 
berkembang. Uji menunjukkan sensasi rasa dan aroma produk yang kuat dan butuh modifikasi karena tidak satupun dari nilai rata-rata aspek penilaian yang menyatakan suka (skor 5).

\section{UCAPAN TERIMA KASIH}

Ucapan terima kasih penulis haturkan kepada PT United Tractors Tbk selaku donatur kegiatan dan Human Initiative yang bertindak sebagai fasilitator serta Mahasiswa/I Teknik Kemasan Politeknik Media Kreatif yang memberikan kontribusi dalam penyusunan laporan penelitian ini.

\section{DAFTAR PUSTAKA}

Ahmad, A. \& Viljoen, A. (2015). The in vitro antimicrobial activity of Cymbopogon essential oil (lemon grass) and its interaction with silver ions. Phytomedicine 22, 657-665

Anto, A. \& Rato, R. (2018). Pengaruh Penambahan Bubuk Kayu Manis (Cinnamomum burmannii) terhadap Sifat Kimia dan Total Mikroba pada Nugget Ayam. Agropolitan 5, 1-11

Bambang, A. G. (2014). Analisis cemaran bakteri coliform dan identifikasi Escherichia coli pada air isi ulang dari depot di Kota Manado. Pharmacon 3,.

Badan Standardisasi Nasional. (2009).SNI 7388:2009 Mengenai Batas Maksimum Cemaran Mikroba dalam Pangan.

Badarinath, A. V et al. (2010). A review on invitro antioxidant methods: comparisions, correlations and considerations. Int. J. PharmTech Res. 2, 1276-1285.

Badami, S. \& Moorkoth, S. Caesalpinia sappan. (2004).A medicinal and dye yielding plant.

Bender, C., Graziano, S., Zimmerman, B. F. \&
Weidlich, H. H. (2014).Antioxidant potential of aqueous plant extracts assessed by the cellular antioxidant activity assay. Am. J. Biol. Life Sci 2, 72 79.

Bredie, W. L. P. \& de Boer, E. (1992). Evaluation of the MPN, Anderson-Baird-Parker, Petrifilm E. coli and Fluorocult ECD method for enumeration of Escherichia coli in foods of animal origin. Int. J. Food Microbiol. 16, 197-208

Chandrasekara, A. \& Shahidi, F. (2018). Herbal beverages: Bioactive compounds and their role in disease risk reduction - A review. J. Tradit. Complement. Med. 8, 451-458 .

Chrubasik, S., Pittler, M. H. \& Roufogalis, B. D. (2005).Zingiberis rhizoma: A comprehensive review on the ginger effect and efficacy profiles. Phytomedicine 12, 684-701

Fachriyah, E. (2012). Identifikasi Minyak Atsiri Biji Kapulaga (Amomum cardamomum). J. SAINS DAN Mat. Vol. 15 Issue 2 Year 2007

Gao, H. et al. (2013). Beneficial effects of Yerba Mate tea (Ilex paraguariensis) on hyperlipidemia in high-fat-fed hamsters. Exp. Gerontol, 572-578.

Goes, T. C., Ursulino, F. R. C., Almeida-Souza, T. H., Alves, P. B. \& Teixeira-Silva, F. (2015). Effect of Lemongrass Aroma on Experimental Anxiety in Humans. $J$. Altern. Complement. Med. 21, 766-773

Hernandez, E. (2000). ESSENTIAL OILS | Distillation. in (ed. Wilson, I. D. B. T.-E. of S. S.) 2739-2744 (Academic Press, 2000). doi:https://doi.org/10.1016/B0-12226770-2/04841-9.

Laplante, J. (2016). Becoming-Plant: Jamu in Java, Indonesia. in Plants and Health: New Perspectives on the HealthEnvironment-Plant Nexus (eds. Olson, E. A. \& Stepp, J. R.). Springer International Publishing, 2016, 17-65. 
Michon, C., O'sullivan, M. G., Sheehan, E., Delahunty, C. M. \& Kerry, J. P. (2010). Study on the influence of age, gender and familiarity with the product on the acceptance of vegetable soups. Food Qual. Prefer. 21, 478-488 Molyneux, P. (2004).The use of the stable free radical diphenylpicrylhydrazyl (DPPH) for estimating antioxidant activity. Songklanakarin J. Sci. Technol 26, $211-$ 219

Nirmal, N. P., Rajput, M. S., Prasad, R. G. S. V \& Ahmad, M. Brazilin (2015). Caesalpinia sappan heartwood and its pharmacological activities: A review. Asian Pac. J. Trop. Med. 8, 421-430.

Otles, S. \& Cagindi, O. (2012). Safety Considerations of Nutraceuticals and Functional Foods BT - Novel Technologies in Food Science: Their Impact on Products, Consumer Trends and the Environment. in (eds. McElhatton, A. \& do Amaral Sobral, P. J.). Springer New York 2012, 121-136.

Parthasarathy, V. A. \& Prasath, D. (2012). Cardamom. in Woodhead Publishing Series in Food Science, Technology and Nutrition (ed. Peter, K. V. B. T.-H. of H. and S. (Second E.) 131-170 (Woodhead Publishing, 2012). doi:https://doi.org/10.1533/97808570956 71.131 .

Pasqualone, A., Summo, C., Laddomada, B., Mudura, E. \& Coldea, T. E. (2018) Effect of processing variables on the physicochemical characteristics and aroma of borş, a traditional beverage derived from wheat bran. Food Chem. 265, 242-252.

Pecore, S. \& Kellen, L. (2002).A consumerfocused QC/sensory program in the food industry. Food Qual. Prefer. 13, 369-374

Periasamy, G., Karim, A., Gibrelibanos, M., Gebremedhin, G. \& Gilani, A. (2016).H. Chapter 69 - Nutmeg (Myristica fragrans
Houtt.) Oils. in (ed. Preedy Flavor and Safety, V. R. B. T.-E. O. in F. P.) Academic Press 607-616.

Ravindran, P. N. \& Babu, K. N. (2016) Ginger: the genus Zingiber. CRC press.

Rini, A. (2019) Industri Minuman Ringan Diproyeksi Tumbuh 3\%, Ini Pemacunya..

Sangadkit, W., Rattanabumrung, O., Supanivatin, P. \& Thipayarat, A. (2012). Practical coliforms and Escherichia coli detection and enumeration for industrial food samples using low-cost digital microscopy. Procedia Eng. 32, 126-133

Shu, Y. et al. (2016). Excess of dietary benzoic acid supplementation leads to growth retardation, hematological abnormality and organ injury of piglets. Livest. Sci. 190, 94-103

Surono, I. S. Ethnic Fermented Foods and Beverages of Indonesia. (2016). in Ethnic Fermented Foods and Alcoholic Beverages of Asia (ed. Tamang, J. P.) 341-382 (Springer India, 2016). doi:10.1007/978-81-322-2800-4_14.

Teves, K. L. Y. (2016).HAZARD ANALYSIS CRITICAL CONTROL POINT (HACCP) CERTIFICATION OF MICRO AND SMALL SCALE FOOD COMPANIES IN THE PHILIPPINES. MATTER Int. J. Sci. Technol.

Thiagarajah, K., Ong, M. K., Teh, L. K. \& Lye, H. S. 13. (2019). Plants Infused Water as Preferred Healthy Drinks. in Bottled and Packaged Water (eds. Grumezescu, A. M. \& Holban, A. M.). Woodhead Publishing, 367-402.

Thomson, D. M. H. \& MacFie, H. J. H. (1994). Measurement of food preferences. Springer.

Winarti, C. \& Nurdjanah, N. (2005). Peluang tanaman rempah dan obat sebagai sumber pangan Tristantini, D., Ismawati, A., Pradana, B. T. \& Jonathan, J. G. (2016). Pengujian Aktivitas Antioksidan 
Masnar , 2020

Menggunakan Metode DPPH pada Daun

Tanjung (Mimusops elengi L). in Seminar

Nasional Teknik Kimia Kejuangan 1

WHO. (2005).Concise International Chemical Assessment Document 26.

Winarsi, H., Sasongko, N. D., Purwanto, A. \& Nuraeni, I. (2013) Ekstrak Daun Kapulaga Menurunkan Indeks Atherogenik dan Kadar Gula Darah Tikus Diabetes Induksi Alloxan. agriTECH; Vol 33, No 3 (2013)DO - 10.22146/agritech.9548 .

Yusop, S. M., O’sullivan, M. G., Kerry, J. F. \& Kerry, J. P. (2009).Sensory evaluation of indian- style marinated chicken by malaysian and european naïve assessors. J. Sens. Stud. 24, 269-289

Zulfahmi, Z. \& Nirmagustina, D. E. (2017). Pengaruh Sukrosa Terhadap Kandungan Total Fenol Minuman Rempah Tradisional (Minuman Secang). J. Penelit. Pertan. Terap. 12, 